\title{
Understanding Leadership Style: A Comparative Study of Women Entrepreneurs Vs Working Women \\ ${ }^{1}$ Sunita Dhote, ${ }^{2}$ Prachita Patil, ${ }^{3}$ Dr.Yogesh Deshpande \\ ${ }^{1}$ Assistant Professor, Dept. of Management, Shri Ramdeobaba College of Engineering and Management, Nagpur \\ ${ }^{2}$ Research Scholar, Dept. Of Humanities and SS, VNIT Nagpur \\ ${ }^{3}$ Professor, Dept. Of Humanities and SS, VNIT Nagpur \\ Email:dhotesn@rknec.edu,prachipatil2112@gmail.com,drymdeshpande@gmail.com
}

Received: $20^{\text {th }}$ September 2018, Accepted: $11^{\text {th }}$ October 2018, Published: $31^{\text {st }}$ October 2018

\begin{abstract}
Research suggests that women handle emotions and relationships in a unique way. The rising proportion of women in the recent era is increasing and has been a major contribution to the nation's economy. Still, the question arises is women possess different leadership style? With the recent innovation hub, the creative world and advances in technology the demand for effective leadership of educated class as well as dynamic women is increasing who really vouch for contributing to the economic growth of nations. Understanding the plethora of overall competitive world, the paper elaborate different leadership style of women working as an entrepreneur and in service sectors. A sample study of 120 women working with various sectors was collected from Nagpur Region. Data were obtained from the face-to-face questionnaire survey and semi-structured interviews. Overall Research Data was collected from entrepreneurs working in diversified fields of Manufacturing, Technology, Retails, and Fashion Designing etc and also from service sectors working in various fields. A detailed comparison was made of women as entrepreneurs with non-entrepreneurs with the help of using T-test of significance to identify the leadership style working in their respective sectors. This paper will provide a unique contribution for the researchers to explore the leadership style working with various fields. It is hoped that findings derived from this study will instigate the development of a theoretical framework on leadership style of women in Nagpur Region.
\end{abstract}

\section{Keywords}

Women, Entrepreneur, Working Women, Leadership Style, Nagpur Region, Questionnaire Method, Semi-StructureInterview.

\section{Introduction}

Women entrepreneurship with the men's bastion has crossed the boundaries of the transition phase and still in a race to achieve as a successful business giant. Women in the position of leadership include managers, directors, politicians, judges, scientists, and entrepreneur or managers. Women start their own business and due to their leadership attitude they possess a tendency to hire employees' especially female employees who can understand the needs of a female customer. With their motivating, guiding and directing style; women can achieve a far better style of leadership as an entrepreneur. These programs considering female employees will be necessary to obtain successful performance for the woman entrepreneur. So the leadership style of woman entrepreneur should be the high consideration. With the past decades, economic fluctuation, technological changes, privatization, with the global economy there has been drastic changes in the short term profit to reshape organizations, trust in an employee's as a leader, the rise of new styles and their leadership. Women prior to coming as an entrepreneur where lacking the moral confidence and self-attitude which restrict them to be in front stand as a leader and put forth their opinion. Women with the 21 st century are coming and standing front irrespective of every field where they can be a good motivator, directing others or controlling employees as well as an organization. Considering the working women, they have to raise their voices, form their union as a woman, and stand in every situation in the coming era. With this keeping in mind, this paper presents an overall perspective of working women and entrepreneurs and their leadership style towards subordinates and employees.

Prior to an economic downturn at the beginning of mid-2008, many women in an organization who were confined to the lower and middle management level denied an opportunity to move into upper management (Dencker, 2008). They took their experience and successful management style with them (Moore \&Buttner, 1997; Moore, 2000, 2010 a). With a $75 \%$ failure rate for startup companies that take venture capital (Hann, 2013); there is a need for leadership skills for a transition of a business from the startup stage to a successful business. 


\section{Women as Leaders}

A female leader is likely to view her position in terms of sharing team members, subordinates in reaching their performance goals (Paris et al., 2009). As an entrepreneur, women with their interactive approach encourages creativity and ultimately balanced the authorities command and controlling behavior apart from a male boss with the more collaborative language and communication styles expected of a woman (Moore, 2000, pp. 100-6). Women (Bass, 1990; Eagly et al., 2003) are particularly effective in people development, role modeling and communicating mutual expectations, rewards and responsibilities.

Women behave more democratically then men in leadership situations use interactive and participative skills, maintaining effective working relationship with employees, subordinates, cooperating with customers that serve to further organizational goals by achieving outcomes that address the concerns of all parties involved (Rosener, 1990, 1997; Moore \&Buttner, 1997; Buttner, 2001; Moore, 2000, 2010a; Eagly\& Carli, 2003; Eagly, Johannesen-Schmidt \& van Engen, 2003).

\section{Literature Review}

Leadership style (Freeman and Siegfried, 2015) according to authors during starts up and growth phases are completely different. While starting a business, some can start with entrepreneurial leadership style sustaining that leadership style still end and some may require enriching within them for achieving success in business. Well functioned leadership style creates a climate of trust and thereby developing a free exchange of information which is necessary for entrepreneurs to avoid barriers in work. (Mannix and Neale, 2005, pp. 41-2)

If work environment became diverse women moved into work role and they encountered various obstacles like hostile work climate, a harsh behavior of seniors, overstressed work for women leading to an improper style of leadership. (Kossek et al., 2003). Women have to first overcome their outsider status, meet the requirement as more stringent than male counterparts, in order to avoid backlash once they placed in a position of leadership(Tharenou, 1999; Oakley, 2000). In a high trust climate, people show a greater level of loyalty, satisfaction and free exchange of information which may lead to taking better and quicker decisions resulting in higher performance (Morrison and Robinson, 1997). There are different leadership styles studied by CEO's, top executives and employees(Engelen, Gupta, Strenger, \&Brettel, 2015; Ling, Simsek, Lubatkin, \&Veiga, 2008b; Waldman, Ramirez, House, \&Puranam, 2001). Thus different leadership styles can exhibit an individual to influence the output performance of employees. (McClesky, 2014).

As a leader female entrepreneurs should spend more time in customer engaging, networking, doing market study and can enhance their knowledge in strategic planning, and leading changes; (Greve, and Salaff 2003; Lerner, Brush, and Hisrich 1997; Morris, Miyasaki, Watters, and Coombes 2006) with their innovation and creativity. (Hisrich, and Brush 1984; Sexton, and Bowman Upton 1990).

\section{Women Leaders and their Characteristics}

Task-Focused -Women as a leader needs to be task focused for completion of project allocated. As a day to day activity if a woman is planned and target oriented she would be a good leader as an entrepreneur or as a working women.

Transformational Leadership Style- Transformational leaders develop themselves as a role model and mentor, empower and encourage the followers to utilize their full potential and equally contributing effectively for organizations"(Eagly\& Carli, 2007). A transformational leader is one who gains the trust and confidence of employees and enhances them to contribute to the betterment of the organization. If a woman inhibits such type of leadership she would be able to renovate and develops business models.

Team Oriented-A leader has to work in a team for better completion of a project within the stipulated duration. Thus a woman has to be work with a team and coordinates the member and be interactive, participative for gaining effective leadership.

Better Cooperation with Employees-As a women leader, if the coordination with employees is better to work will be managed effectively. A woman has to better understand the problems of employees, married women problems, feeding women etc and has to cooperate with them properly.

Mentoring Others-Everyone needs a mentor for guidance and support. A woman has to be a mentor for guiding and training employees as per the necessity and requirement.

\section{Aim}

The Aim of study is to understand leadership style of women working as entrepreneurs and non-entrepreneurs. 


\section{Objectives}

- To examine the leadership approach of women entrepreneurs and working women.

- To understand lacking factors of leadership styles of women.

- To analyze participative styles of women with subordinates as a leader.

\section{Research Methodology}

Primary data was collected with the help of a structured questionnaire, wherein $(\mathrm{N}=120)$. A sample of total 60 women entrepreneurs and 60 working women in various sectors were taken from various regions of Central India. The research used a Likert scale to test the leadership style of women in which reliability is found to be 0.91 and validity is 0.95 . The questionnaire had 41 items, which were divided in 11 factors namely Interpersonal skills, analytical skills, ability to monitor, ability to organize, ability to be tactful, ability to inspire, ability to motivate, positive approach, ability to solve problems, knowledgeable and accommodative.

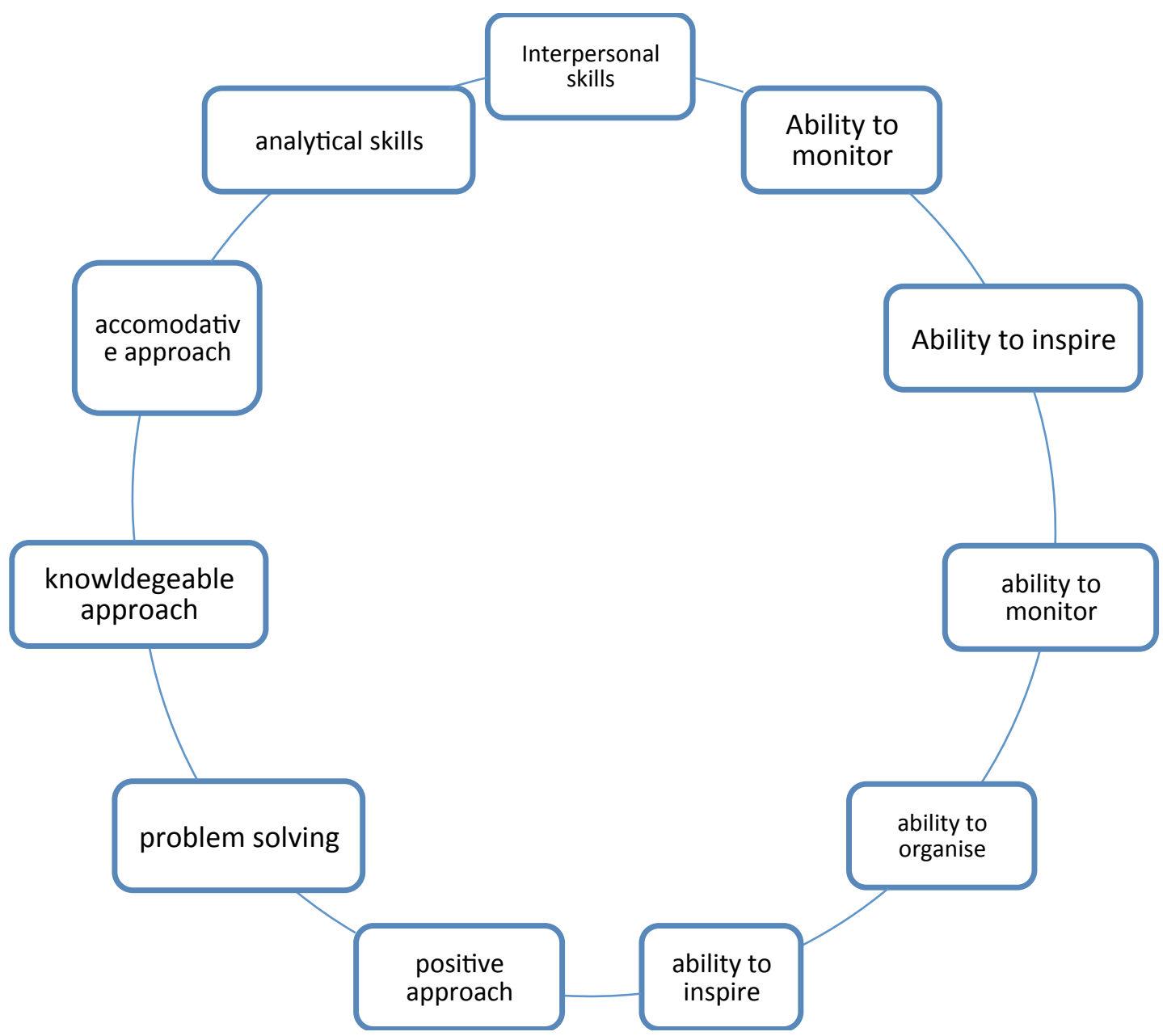

Figure 1: Women Entrepreneur and their Factors

\section{Hypothesis}

$\mathrm{H} 0=$ There is no significant difference between the interpersonal skills of women entrepreneurs and working women. $\mathrm{H} 1=$ There is a significant difference between the interpersonal skills of women entrepreneurs and working women.

$\mathrm{H} 0=$ There is no significant difference between the analytical skills of women entrepreneurs and working women. $\mathrm{H} 2=$ There is a significant difference between the analytical skills of women entrepreneurs and working women.

$\mathrm{H} 0=$ There is no significant difference between the Ability to Monitor skills of women entrepreneurs and working women. 
$\mathrm{H} 3=$ There is a significant difference between the Ability to Monitor skills of women entrepreneurs and working women.

$\mathrm{H} 0=$ There is no significant difference between the Ability to organize skills of women entrepreneurs and working women.

$\mathrm{H} 4=$ There is a significant difference between the Ability to organize skills of women entrepreneurs and working women.

$\mathrm{H} 0=$ There is no significant difference between the Ability to be tactful skills of women entrepreneurs and working women.

H5=There is a significant difference between the Ability to be tactful skills of women entrepreneurs and working women.

$\mathrm{H} 0=$ There is no significant difference between the Ability to Inspire skills of women entrepreneurs and working women.

H6=There is a significant difference between the Ability to Inspire skills of women entrepreneurs and working women.

$\mathrm{H} 0=$ There is no significant difference between the Ability to motivate skills of women entrepreneurs and working women.

$\mathrm{H} 7=$ There is a significant difference between the Ability to motivate skills of women entrepreneurs and working women.

$\mathrm{H} 0=$ There is no significant difference between the positive approach of women entrepreneurs and working women.

$\mathrm{H} 8=$ There is a significant difference between the positive approach of women entrepreneurs and working women.

$\mathrm{H} 0=$ There is no significant difference between the ability to solve problem approach of women entrepreneurs and working women.

H9=There is a significant difference between the ability to solve problem approach of women entrepreneurs and working women.

$\mathrm{H} 0=$ There is no significant difference between the knowledgeable approach of women entrepreneurs and working women.

$\mathrm{H} 10=$ There is a significant difference between the knowledgeable approach of women entrepreneurs and working women.

$\mathrm{H} 0=$ There is no significant difference between the accommodative approach of women entrepreneurs and working women.

H11=There is a significant difference between the accommodative approach of women entrepreneurs and working women.

Data Analysis

\begin{tabular}{|c|c|c|c|c|c|}
\hline Sr. No. & Factors & Statistic Tools & $\begin{array}{l}\text { Women } \\
\text { Entrepreneurs }\end{array}$ & $\begin{array}{l}\text { Working } \\
\text { Women }\end{array}$ & $\begin{array}{l}P(T<=t) \\
\text { two-tail }\end{array}$ \\
\hline \multirow[t]{3}{*}{1.} & \multirow{3}{*}{ Interpersonal Skills } & $\mathrm{P}$ value & & & $1.13 \mathrm{E}-17$ \\
\hline & & Mean & 1.714286 & 1.930357 & \\
\hline & & Variance & 0.161882 & 0.608189 & \\
\hline \multirow[t]{3}{*}{2.} & \multirow{3}{*}{ Analytical Skills } & $P$ value & & & $1.05 \mathrm{E}-18$ \\
\hline & & Mean & 1.612994 & 1.94774 & \\
\hline & & Variance & 0.100997 & 0.658261 & \\
\hline \multirow[t]{3}{*}{3.} & \multirow{3}{*}{ Ability To Monitor } & P value & & & $1.73 \mathrm{E}-15$ \\
\hline & & Mean & 1.711864 & 1.994915 & \\
\hline & & Variance & 0.142443 & 0.836698 & \\
\hline 4. & Ability To Organize & $\mathrm{P}$ value & & & $4.11 \mathrm{E}-17$ \\
\hline
\end{tabular}




\begin{tabular}{|c|c|c|c|c|c|}
\hline & & Mean & 1.677966 & 1.819209 & \\
\hline & & Variance & 0.233587 & 0.514644 & \\
\hline \multirow[t]{3}{*}{5.} & \multirow[t]{3}{*}{ Ability To Be Tactful } & $P$ value & & & $1.69 \mathrm{E}-13$ \\
\hline & & Mean & 1.774011 & 1.805085 & \\
\hline & & Variance & 0.170271 & 0.651487 & \\
\hline \multirow[t]{3}{*}{6.} & \multirow{3}{*}{ Ability To Be Inspire } & $P$ value & & & $4.61 \mathrm{E}-17$ \\
\hline & & Mean & 1.759322 & 1.983503 & \\
\hline & & Variance & 0.198317 & 0.626088 & \\
\hline \multirow[t]{3}{*}{7.} & \multirow[t]{3}{*}{ Ability To Motivate } & $P$ value & & & $2.5 \mathrm{E}-15$ \\
\hline & & Mean & 1.711864 & 1.90678 & \\
\hline & & Variance & 0.142443 & 0.73685 & \\
\hline \multirow[t]{3}{*}{8.} & \multirow{3}{*}{ Positive Approach } & $\mathrm{P}$ value & & & $1.32 \mathrm{E}-15$ \\
\hline & & Mean & 1.538136 & 1.847458 & \\
\hline & & Variance & 0.172012 & 0.853485 & \\
\hline \multirow[t]{3}{*}{9.} & \multirow{3}{*}{ Problem Solving } & $\mathrm{P}$ value & & & $7.57 \mathrm{E}-14$ \\
\hline & & Mean & 1.669492 & 1.957627 & \\
\hline & & Variance & 0.281122 & 0.968001 & \\
\hline \multirow[t]{3}{*}{10.} & \multirow{3}{*}{ Knowledgeable Approach } & $\mathrm{P}$ value & & & $1.94 \mathrm{E}-10$ \\
\hline & & Mean & 1.830508 & 2.169492 & \\
\hline & & Variance & 0.660432 & 1.453536 & \\
\hline \multirow[t]{3}{*}{11.} & \multirow{3}{*}{ Accommodative Approach } & $P$ value & & & 4.47E-14 \\
\hline & & Mean & 1.59322 & 1.944444 & \\
\hline & & Variance & 0.452367 & 0.845912 & \\
\hline
\end{tabular}

Data Analysis of all 11 factors was done using t-test of unequal variance, as there indeed a significant difference between the variables. The data interpretation shows comparison of entrepreneurs and working women.

\section{Data Interpretation}

With the data analysis of different factors, it has been found that $\mathrm{P}(\mathrm{T}<=\mathrm{t})$ two-tail is less than 0.05 of all the factors thus it shows a significant difference between women entrepreneurs and working women which is a positive state of a sign. Higher, the ability to be motivated or risk-taking more leadership style would be found in entrepreneurs than working women. Women when having a positive approach, or interpersonal skills and have the ability to monitor people can have more leadership quality which can be seen in women entrepreneur, as they are strong enough to deal with customers, employees, take a risk, be flexible enough and tactful to handle each situation.

\section{Discussion and Conclusion}

The paper findings contribute to the entrepreneurial skills of women working in different fields. In conclusion one can argue that women entrepreneurs are capable of risk-taking, handling customer relations, interpersonal skills, ability to motivate, risk taking abilities and positive at work. The overall paper was analyzed and compares on the basis of working women and entrepreneurs. The purpose of this paper was to identify various skills and leadership approach with women of different sectors. However, with the statistical analysis, it has been clearly seen that although mean of working women with respect to women entrepreneurs is large but considering the $\mathrm{P}(\mathrm{T}<=\mathrm{t})$ twotail it is negative, which states that there is a significant difference between working and women entrepreneurs. As with the current scenario women are seen in every sector and if they don't have leadership style they will fail to achieve a success of ladder. Being a working woman she has to be multitasked with an efficient potential to handle colleagues, boss, staff etc. A working woman has to be updated with enough skills and knowledge and has to satisfy a superior person for increments, performance appraisal, and promotion etc. But with women entrepreneurs, she has to handle employees, staff, partners, and customers and has to guide everyone with different leadership approach. She has to guide everyone in having leadership styles. Thus we can conclude that women have enough talent to show inner potential with the effectiveness of leadership and can equally contribute for profitability and well being which encompasses participants and entrepreneurial objectives as well as the surrounding environment. 


\section{References}

[1]A career without boundaries. Palo Alto, CA. Davies-Black Publishing. Dorothy Perrin Moore Jamie L. Moore Jamie W. Moore, (2011),"How women entrepreneurs lead and why they manage that way", Gender in Management: An International Journal, Vol. 26 Iss 3 pp. 220 - 233.

[2]Bass, B. M., 1990,Leadership and performance beyond expectations(2nd ed.). New York: Free Press.

[3]Corbett, A. 2007, "Learning asymmetries and the discovery of entrepreneurial opportunities". Journal of Business Venturing, 22: 97-118.

[4]Eagly, A. H. and Johannesen-Schmidt, M. C., 2001,“The leadership styles of women and men”. Journal of Social Issues, 57: 781-797.

[5]Eagly, A. H., \& Carli, L. L. 2003. The female leadership advantage: An evaluation of the evidence. Leadership Quarterly, 14: 807-835.

[6]Eagly, Alice H and Carli, Linda A. 2007. Women and the Labyrinth of Leadership.

[7]Editor, Gender and Women's Leadership: A Reference Handbook: 443-451. Thousand Engagement Through Effective Performance Management: 31-66. UK. Taylor \&Francis Ltd. Routledge Academic Press.

[8]Elliott, C. and Stead, V., 2008, "Learning from leading women's experience: towards a sociological understanding". Leadership, 4: 159-180.

[9]Johnson, S. K., Murphy, S. E., Zewdie, S. \&Reichard, R. J. 2008. The strong, sensitive type: Effects of gender stereotypes and leadership prototypes on the evaluation of male and female leaders. Organizational Behavior \& Human Decision Processes, 106(1): 39-60

[10]Journal, 27: 603-618. Kossek, E.E., Markel, K.S. and McHugh, P.P. (2003), "Increasing diversity as an HRM change strategy", Journal of Organizational Change Management, Vol. 16 No. 3, pp. 328-52.

[11]Kirkwood, J. and Tootell, B., 2008,“Is entrepreneurship the answer to achieving work-family balance?’Journal of Management and Organization, 14: 285-302.

[12]Lee-Gosselin, H. and Grise, J., 1990, "Are women owner-managers challenging our definitions of entrepreneurship? An in-depth survey”. Journal of Business Ethics, 9: 423-435.

[13]Lerner, Miri, Brush, Candida and Hisrich, Robert (1997). 'Israeli Women Entrepreneurs: An Examination of Factors Affecting Performance,' Journal of Business Venturing, 12(4), 315-339.

[14]Mannix, E. and Neale, M.A. (2005), "What differences make a difference? The promise and reality of diverse teams in organizations", Psychological Science in the Public Interest, Vol. 6 No. 2, pp. 31-55.

[15]Moore, D. P. 1984. Evaluating in-role and out-of-role performers. Academy of Management

[16]Moore, D. P. 2000. Careerpreneurs: Lessons from leading women entrepreneurs on building

[17]Moore, D. P. 2010a. Women as Entrepreneurs and Business Owners. In Karen O'Connor,

[18]Moore, D. P., \&Buttner E. H. 1997. Women entrepreneurs: Moving beyond the glass ceiling.

[19]Moore, D.P. (2000), Careerpreneurs: Lessons from Leading Women Entrepreneurs on Building a Career without Boundaries, Davies-Black Publishing, Palo Alto, CA.

[20]Moore, J. L. 2010b. Building a climate of trust. In E. M. Mone\& M. London (Eds.), Employee Engagement Through Effective Performance Management: 31-66. UK. Taylor \& Francis Ltd. Routledge Academic Press.

[21]Moore, J. L. 2010b. Building a climate of trust. In E. M. Mone\& M. London (Eds.), Employee

[22]Morris, Michael H., Miyasaki, Nola N., Watters, Craig E. and Coombes, Susan M. (2006). 'The Dilemma of Growth: Understanding Venture Size Choices of Women Entrepreneurs,' Journal of Small Business Management, 44(2), 221-244.

[23]Morrison, E.W. and Robinson, S.L. (1997), "When employees feel betrayed: a model of how psychological contract violation develops", Academy of Management Review, Vol. 22 No. 1, pp. 226-56.Oaks, CA. Sage.

[24]Paris, L.D., Howell, J.P., Dorfman, P.W. and Hanges, P.J. (2009), "Preferred leadership prototypes of male and female leaders in 27 countries", Journal of International Business Studies, Vol. 40 No. 8, pp. 1396-405.

[25] Rosener, J. B. 1990. Ways women lead. Harvard Business Review, 68(6): 119-125.

[26]Sexton, Donald L. and Bowman-Upton, Nancy (1990). 'Female and Male Entrepreneurs: Psychological Characteristics and Their Role in Gender-Related Discrimination,' Journal of Business Venturing, 5(1), 29-36.

[27]Tharenou, P. (1999), "Gender differences in advancing to the top", International Journal of Management Reviews, Vol. 1 No. 2, pp. 11-33.Thousand Oaks, CA. Sage. 